\title{
İbnu'l-Enbari ve Eserleri
}

\section{Prof. Dr. Ahmet Suphi FURAT ${ }^{1}$}

\begin{abstract}
$\ddot{\mathbf{O} z}$
İbnu'l-Enbârî, 271/884 yılında Bağdat'ın batısında yer alan Enbâr'da doğmuş ve 327/938 yılında da Bağdat'ta vefat etmiş bir dil âlimidir. O, çağdaşı biyoğrafi yazarları tarafindan önde gelen dil âlimleri arasında kaydedilip ele alınmıştır. Öğrenimini önce Enbâr'da yine bir dilci olan babasının yanında aldı. Daha sonra on iki yaşında, babasıyla gittiği Bağdat'ta Kûfe dil ekolünün başı olan Sa'leb'in ders halkasında ilerletti. Çağdaşı biyoğrafi yazarları onun özellikle dilbilgisindeki geniş vukûfunu medh eder.

İbnu'l-Enbârî, içinde gramer, edeb, Kur'an filolojisi ve şiirin yer aldığı çeşitli alanlarda eserler yazdı. Bunları herhangi bir kitaba bakmadan yazdırdığı rivayet edilir. Öyle görülüyor ki bu metot, onun özellikle gramer ve şiir sahasında bazı eserlerinin günümüze ulaşamamasına sebep olmuştur. Bu makale, İbnu'l-Enbârî'nin hayatı ve çalışmalarını etraflıca ele almaktadir.
\end{abstract}

Anahtar Kelimeler: İbnul-Enbari, Enbar, Kufe, Bă̆dat, Arap dili.

\footnotetext{
1 Prof. Dr. Ahmet Suphi Furat, İstanbul Aydın Üniversitesi Eğitim Fakültesi, Arap Dili Eğitimi Bölümü / asuphifurat@aydin.edu.tr
} 


\title{
İbnu'l-Enbârî and His Works
}

\begin{abstract}
İbnu'l-Anbari is an Arab grammarian, who was born in 271/884 at Enbar (in the vicinity of West Baghdad) and died in 327/938 at Baghda. He was recorded among the famous Kûfan grammarians by his contemporary biographers. He studied first by his father, who was also o philologist, at his hometown Anbar. Afterwards, at the age of 12 , he went to Baghdad in the company of his father, where he advanced his studiesin the circle of Sa'leb, the head of the Uuffan grammer school. The contemporary biographares praised his skills of learning, particularly in the field of grammer and extensity of hia knowledge.
\end{abstract}

İbnu'l- Anbari has written on a written on a variety of subjects, including grammer, adab, Quranic studies and poetry. It was reported that he had dictated many of his Works directly from his memory, whithout looging at any book. It appears that any book. It appears that this method caused the the absenc of several of his works, particulary in the field of grammar and poetry. He was a prolific writer and scholar, as is proven by his Works, which are discussed in details in this paper.

Keywords: Ibnul - Enbari, Enbar, Kufa, Baghdad, Arabic language.

Hicri IV/X. asra ait kaynakların müellifleri, muasırları sayılabilecek Ebu Bekr İbn el-Enbari'yi (büyük bir) nahiv âlimi olarak tanıtırlar. Mesela bunlar arasında İbnu'n-Nedim, h. 377/987 de kaleme aldığı ve bir bilimler tarihi olan kitabı el-Fihrist'te onu 'Ahbar en-nahviyyin ve 1-lugaviyyin elkufiyyin' başlıklı bölümde Kufe dil mektebine mensup değerli bir nahiv âlimi olarak ele alır (s. 64). H.379/989'de vefat eden İşbiliye kadısı ezZubeydi, Tabakatu'n-Nahviyyin ve'l-lugaviyyin'inde alimimizi, Kufeli nahivcilerden Sa'leb'in talebeleri arasında zikreder (s. 153-154). Daha sonraki asırlarda yaşamış müelliflerden hemşehrisi dilci ve edip Ebu 1Berekat İbn el-Enbari'nin (v.577/1181) Nuzhetu'l- elibba'sinda, edip ve cogyafyac1 Yakut el-Hamevi'nin (v.626/11229) Mu'cemu'l-udeba'sinda, Halebli vezir ve kültür tarihçisi el-Kıfti'nin (v.646/1248) İnbahu'rruvat'"ında da benzer değerlendirmeleri buluyoruz. Abdurrahman 
Fehmi Bey de onu, dil alimleri arasında parlayan bir yıldız olarak görür (Medreset el-Arab , Kostantıniye, 1888; I,63).

Bütün bunlar, İslam dünyası dışında olup ta Arap dil ve edebiyatı ile ilgilenen araştırmacıların da kaynaklarını oluşturmuştur. Alman müsteşrik C. Brockelmann (v. 1956), Arap edebiyatı tarihine ait Geschichte der Arabischen Litteratur'unda (1898) onu, h. III/IX. asırda oluşan Kufe dil mektebinin önde gelen mümessili Sa'leb'in mühim bir talebesi olarak işler (GAL I, 119-120). O daha sonra bu eserine yaptığı zeyilde (1937) daha çok, âlimimizin eserleri üzerinde duracak ve onun bazı mühim eserlerini ülkemiz kütüphanelerindeki yazmaları ile tanıtacaktır (S I 182-183). Hocam Prof. Dr. Fuat Sezgin (v. 2018) eseri Geschichte des Arabischen Schrifttums'da bu büyük âlimi, ilgilendiği alanları dikkate alarak, Arap edebiyatında lüğatçılığı işlediği VIII. cilt (s. 151-154) ile nahvi konu edindiği IX. ciltte (s. 144-147) hayatı ve eserleri hakkında bugüne kadar yapılmış çalışmalar ile birlikte yakından tanıtır. ${ }^{1}$

Âlimimizin tam adını (sekiz ceddi ile birlikte) Muhammed b. el-Kasım b. Muhammed b. Beşşar b. el-Huseyn b. Beyyan b. Sema'a b. Ferve b. Katan b. Di'ame Ebu Bekr b. el-Enbari olarak Yakutu'l-Hamevi'nin Mu'cemu'l-udeba'sında görüyoruz (XVIII, 306). ${ }^{2}$ Sahip olduğu Enbari nisbesini doğduğu Enbar'dan almış olmalıdır; sadece el-Merzubani (v. 384/994), ailesinin Samerra'dan geldiğini kaydeder (el-Muktebes, s. 345). Aynı zamanda bir şehirler lügati da yazmış olan Yakutu'l-Hamevi, bugün Irak'ta Firat nehrinin sol kiyısında harabeler halinde bulunan Enbar hakkında ana hatlarıyla şunları söyler: Bağdat'ın batısında Fırat nehri kıyısında bir şehirdir. İranlılar ona Firuzsabur derler. Onu ilk defa mamur

\footnotetext{
${ }^{1}$ Bu vesile ile burada Ahmet İhsan Türk'ün doktora tezi olarak hazırladığı Ebû Bakr Muhammed İbni'l-Anbari, Hayatı, Kişiliği, Eserleri ve Kitabu'z-Zahir'i adlı çalışması (1966) ile Emin Işık'ın öğretim üyeliği tezi olarak yazdığı Ebu Bekr Muhammed İbnü l-Enbari ve Kitabu İdahi'l-vakfi ve'l-İbtida Adlı Eserinin Edisyon Kritiği isimli çalı̧̧masını hatırlatalım (1973); ayrıca bk. İbnü’lEnbari, Ebû Bekr, DİA XXI 24-26.

${ }^{2}$ Ayrıca bk. (İnbah III, 201); Vefeyat (IV, 343); Bugye (s. 91).
} 
eden Sabur b. Hurmuz, sonra yenileyen de ilk Abbasi halifesi Ebu'l-Abbas es-Seffah’tır (Mucemu'l-udeba I, 257).

Arap dili ve edebiyatında Enbar'dan yetişen pek çok âlim ve edip bulunmaktadır. Enbar eski bir kültür merkezidir. İ̉bnu'l-Enbari'nin hayatı hakkında en fazla bilgiyi ilk olarak, yine aynı nisbeyi taşıyan hem şehrisi Ebu'l-Berekat Kemaleddin b. Muhammed el-Enbari'nin (v. 577/1181) Nuzhetu'l-elibba fi tabakati'l-udeba'sında buluyoruz. Buradaki kayda göre o, h. 271/884 y1lında doğdu (s. 371). Henüz küçük bir yaşta iken babasıyla birlikte Bağdat'a giden Ebû Bekr M. (Mu'cem el-udeba, XVI,318), asıl eğitimini babasının himayesinde bu şehirde almış olmalıdır. $^{2}$ Halebli dil âlimi Ebu't-Tayyib el-Lugavi (v. 351/962) Meratibu'n-nahviyin'in de (s. 95-96) Kufe dil mektebinin iki büyük âlimi İbnu's-Sikkit ile Sa'leb'i hatırlatıp onların nahivdeki hocalarını zikrettikten sonra İbn el-Enbari'nin babası el-Kasım b. Muhammed elEnbari'yi kaydeder. İbnu'n-Nedim el-Fihrist'inde (s. 75) onun K. elEmsal, K. el-Muzekker ve 1-muennes, K. el-Maksur ve'l-memdud adlı eserlerini zikreder, Yakutu'l-Hamevi, Mucemu'l-udeba'sinda (XV,316319); el-Kıfti, İnbah'da (III/28) onun hayatı ve eserleri hakkında bilgi verirler. Müellifimizin babası el-Kasım b. Muhammed el-Enbari, yazdığı nakledilen eserlere bakılırsa lügatçi (sözlük uzmanı) olarak görülmektedir. ${ }^{3}$ Burada ayrıca alimimizin babası el-Kasım'ın Bağdat'ta,

\footnotetext{
${ }^{1}$ Arap dili ve edebiyatına dair pek çok eser neşretmiş olan Muhammed Ebu'l-Fadl İbrahim, Ebu'lBerekat İbnu'l-Enbari'nin neşrettiği Nuzhetu'l-elibba fi Tabakati'l-udeba'sına yazdığı önsözünde eserin sahibini tanıtırken şöyle demişti: Önde gelen nahiv, dil ve edebiyat âlimlerinden sayılan şu üç zat Enbar'a nisbet edilmekle şöhret bulmuştur. Çoğu kimseler bu konuda ve kendilerine eserler isnadında farklı görüşlerde bulunmuştur. Bunların ilki K. Halki'l-insan, K. Halki'l-feres ve K. Garibi'l-hadis sahibi Ebû Muhammed el-Kasım b. Muhammed b. Beşşar el-Enbari; ikincisi Ebû Bekr el-Enbari diye tanınan ve K. el-Addad, Şarihu'l-Mufaddal ve s-seb' et-tival sahibi olan oğlu Muhammed; üçüncüsü de Ebu'l-Berekat Abdurrahman b. Muhammed b. Ebi Ubeydillah b. Ebi Said el-Enbari'dir. Bu sonuncunun lakabı el-Kemal olup K. El-İnsaf fi mesaili'l-hilafiyat ve Nuzhetu'l-elibba fi tabakat el-udeba'nın müellifidir. O eserler tasnifi ve telifi açısından zikredilen bu üç zatın en önde gelenidir.Bizim burada eserleri ile birlikte tanıtmak istediğimiz, bunlardan ikincisi Ebû Bekr Muhammed b. el-Kasım b. Muhammed b. Beşşar el-Enbari'dir. Enbar şehri hakkında detaylı bilgi için bk. İbn el-Enbari, Mu'cem el-buldan I, 257.

${ }^{2}$ Mu'cem el-udebada ki rivayette (XVI, 318) babasının mali imkânlarının o sıralarda kısıtlı olduğu ve bu yüzden elindeki K. el-Ayn'ı satmak zorunda kaldığı anlaşılıyor.

${ }^{3}$ Ayrica bk. GAS VIII, 148.
} 
el-Ferra'nın en önde gelen öğrencisi Seleme b. Asım (v. 240/854), lügatçıllğ 1 yanında şiir ve ahbar ile ilgilenen ve el-Mufaddaliyat'ı rivayet eden (GAS VIII, 135) Ebû İkrime ed-Dabbi ve Kufe dil mektebinin en meşhur mümessili Sa'leb'in (v. 291/904) ders halklarına katıldığını da hatırlatalım.

Mu'tezbillah'ın (ö.255/869) ilk y1llarına rastlayan bu devrede hilafet merkezi Bağdat'ta büyük sıkıntılar ve mali zorluklar yaşanıyordu. Bağdat'ın dışında da tehlikeli gelişmeler söz konusu idi. Mısır'da Tolunoğulları ile süregelen anlaşmazlıklar sonunda halledildi ama Saffarilerden Amr b. Leys'e bırakılan Horasan ve Maveraünnehir bir müddet sonra Samanilere geçmişti. Ancak bütün bu gelişmeler Şii ayaklanmaları için uygun bir zemin hazırlamıştı. Karmatiler Bahreyn'de hâkimiyet sağlamışlar, daha sonraları da Muktefi'nin hilafeti yıllarında (289-295/902-908) Dımaşk'a, Muktedir'in hilafetinde (295-320/908-932) Basra'ya saldırmışlar, er-Razi'nin hilafetinde de Hac yollarında yağmalarda bulunmuşlardı.

İbnu'l-Enbari'nin nahiv ve dil alanında Sa'leb'in (v. 291/904) derslerinden ciddi şekilde etkilendiği anlaş1lıyor. O, h.304/916 yılında Bağdat'ta vefat eden babası henüz hayatta iken, h. 300/912 yılında önünde ders okunan ve 301/913 yılında imla ettiği dersleri yazılan bir âlim (s. 208) olduğunda 29 yaşlarındaydı. Ancak öğrenim devresindeki bu büyük başarısında yaradılışından sahip olduğu meziyetler de unutulmamalıdır. Zeki olduğu, kuvvetli bir hafizaya sahip bulunduğu hemen hemen her kaynakta yer almaktadır ${ }^{1}$. Bütün bunlar onun kısa zamanda yetişmesini sağlamış görülüyor. Ebu'l-Berekat b. el-Enbari ayrıca bu hususla ilgili olarak 'Mescidin bir tarafında babası, diğer tarafında oğlu ders (imla) veriyordu' rivayetini kaydederek olayı adeta canlandırır. ${ }^{2}$ Burada İbnu'nNedim'in şu rivayetini de hatırlatalım. O babasından daha üstün ve bilgili

\footnotetext{
${ }^{1}$ Bk. mesela el-Fihrist, 75; İnbah III, 207.

${ }^{2}$ En-Nuzhe, s. 365; ayrıca bk. Bugye, s. 91; İbn Hallikan bu rivayeti, Tarih Bağdat sahibi el-Hatib el-Bagdadi'den naklen verir: Vefeyat IV, 341.
} 
idi; zekâ, anlayış (fitnat), hafiza ve hazırcevaplıkta en ileri derecedeydi. Ayrıca salih kullar arasında vara sahibi biriydi, hakkında hürmet ve zelle bilinmemektedir. İmla ettiklerinin çoğu, defter ve kitaba bakmadan yazdırdıklarıydı (el-Fihrist s. 75). Ancak hakkı teslim etmekte de tereddüt etmezdi. Bu noktada öğrencisi Ebu'l-Hasan ed-Darakutni ilginç bir olayı anlatır: Cuma günü onun imla meclisinde bulundum. Bir hadisin senedinde sıraladığı bir ismi tashif etti, Hayyan yerine Habban ya da Hıbban demişti. $\mathrm{Bu}$ konudaki üstünlüğüne rağmen böyle bir vehme düşmesini yadırgamıştım. Ona hatırlatmayı düşündüm. İmla sona erince müstemliye gittim, vehmini hatırlattım ve doğrusunu bildirip ayrıldım. Daha sonraki Cuma günü mecliste hazır bulundum. Ebû Bekr b. el-Enbari müstemliye şöyle dedi: Gelen topluluğa bildir: Geçen Cuma hadisi yazdırırken filan isimde hata ettik, genç (arkadaşımız) bunun doğrusunda bizi uyardı (enNuzhe 370). Güneşin ismini açıklarken kendisine yapılan uyarı ile ilgili rivayette de benzer bir tutumunu görüyoruz. ${ }^{1}$

Klasik kaynakların nahiv âlimi olarak tanıttı̆ğ İbnu'l-Enbari'nin bu konuda yazdığı eserler ne yazık ki günümüze ulaşamamıştır. K. el-Kafi fi'n-nahv (el-Fihrist, 75, en-Nuzhe 364; Mu'cem el-udeba XVIII, 313; İnbah III, 208), K. Vadih fi'n-nahv (aynı yerler), K. el-Mudih fi'n-nahv, aynı yerler) bunların başlıcalarıdır. Elimizde olmayan Emali veya Mucalesat'ında da nahivle ilgili meselelere yer vermiş olmalıdır (elFihrist, s. 75, Nuzhe 365). Bu gurupta zikredilebilecek olan K. elMuzekker ve'l-mu'enes'i için el-Hatib el-Bagdadi nin 'Kimse bu konuda daha tam bir eser görmedi dediği rivayet edilir'² Onun K. el-Maksur ve'lmemdud' $u$ da burada hatırlatılmalıdır ${ }^{3}$

İbnu'l-Enbari asıl şöhretini, nahve dair geniş ve güvenilir bilgisiyle ilgilendiği Kur'an bilimleri (filolojisi) alanında sağlamış görülüyor. Kur'an ve hadisle ilgilenişi, bunlarda geçen nadir ve anlaşılması zor

\footnotetext{
${ }^{1}$ Bk. Nuzhetu'l-elibba, 371.

${ }^{2}$ Hk. Bk. Nihat M. Çetin, Şarkiyat Mecmuası I/1956/ s.104-105

${ }^{3}$ Ayrica bk. R. Abduttevvab, Mecellet Kulliyyeti'l-Lugati'1-Arabiyye 7/1977/83 (Riyad)
} 
kelimelerin okunuşu, yazılışı ve açıklanmasına yöneliktir. Abdurrahman Fehmi Bey, onun pek değerli ve meşhur olan Garibu'l-hadis'inin beşbin varak olduğuna dair rivayeti de nakleder (Medresetu'l-Arab I, 63). İbnu'lEnbari'nin Kur'an-1 kerim ile ilgili eserleri şunlardır:

\section{Kitab İzahi'l-vakf ve'l-ibtida}

İbnu'n-Nedim, Kur'an kiraatinde vakf ve ibtidayı konu edinen kitaplar arasında İbnu'l-Enbari'nin bu kitabını da kaydeder (s. 36). Kur'an okurken mananın doğru anlaşılması için gerekli yerlerde durmanın ve ardından da başlamanın ehemmiyeti, bu alanda pek çok eserin yazılmasını sağlamıştır. ${ }^{1}$

Ebu'l-Berekat el-Enbari eseri Nuzhet el-kulub'ta, meşhur vezir es-Sahib b. Abbad'ın (v.385/995) da bu alanda bir eseri olduğunu kaydederek şöyle der: Gençlik yıllarında K. el-Vakf ve 1-ibtida' yı yazdıktan sonra Ebû Bekr İbnu'l-Enbari ona mektup gönderdi ve: Ben K. el-Vakf ve'l-ibtida'y1 ancak bu bilgi dalıyla ilgili yetmiş kitaba baktıktan sonra tasnif ettim. Sen yaşının küçüklüğüne rağmen bu kitabı nasıl yazdın?, dedi. Bunun üzerine es-Sahib elçiye, 'Üstada söyle! Ben bu konuda yetmiş civarında esere baktım, senin kitabına da' demişti (s. 326).

Kitabu'l-İzah ve'l-vakf'ın ülkemiz kütüphanelerinde mevcut nüshaları arasında şunlar bilhassa hatırlatılmalıdır: Reisul küttab 7; 197 var. h. 474/m.1081'ten önce olmalıdır. Selim Ağa 32; 235 var., h.569/m.1173 ; Köprülü 11, 191 var., h.598/m.1201.

\footnotetext{
${ }^{1}$ Nitekim İbnu'n-Nedim bu konu üzerinde eser yazmış şu âlimleri de kaydeder: Hamza (b. Habib el-Kufi et-Temimi, v. 156/773), Halef (b. Hişam el-Bezzaz el-Bagdadi, v.229/844), İbn Sa'dan (İbrahim b. Muhammed, v. 260/873), Dirar b. Surad, Ebû Ömer ed-Duri (Hafs b. Omer v. 240/854) Hişam b. Abdullah, Ebû Abdirrahman el-Yezidi, İbn Keysan (Ebu'l-Hasan Muhammed b. Ahmed v.299912, el-Ca'di (Ebû Bekr Muhammed b. Osman v.320 /932), Ebu Suleyman b.Yahya ed-Dabbi (s. 36). Bu âlimler listesi bize, konunun daha hicri ikinci asırda ele alındığını, hicri üçüncü asırda pek çok âlim tarafindan işlendiğini gösteriyor. Ancak diğer kaynaklara bakıldığında bunlara Ebu Amr b. el-Ala (v.154/771), el-Ahfeşu'l-Avsat (v. 215/830),el-Fadl b. Muhammed el-Ensari (v. hicri üçüncü asır ortaları), es-Sirafi (v 368/979), er-Ru'asi (v.193/809) ve Sa'leb (v.291/904) gibi bazı âlimlerin katılması gerektiği de ortadadır.
} 


\section{K. el-Ha'at fi Kitabillah}

El-Kıfti bu eserin aslında 1000 varak civarında olduğunu kaydeder (İnbah III, 204). Ne yazık ki eserden bir kaç varak günümüze kadar gelebilmiştir: Paris 651/2 (67-68. varaklar). Bu küçük kitap, M. H. Yasin tarafindan Mecelletu'l-Belag'da yayınlanmıştır. (Bağdat, 1975: no. 4-5).

K. Mersumi'l-hatt (K. fihi mersum el-hatt vemahtelefe fihi kurrau elemsar vema t-tefeka aleyhi min zalike ale $\mathrm{t}$-temam ve 1-kemal) Eser, I. Ali Arşi tarafından Yeni Delhi'de yayınlanmıştır (1977).

\section{K. er-Redd ala men halefe Mushaf Osman}

El-Hatibu'l-Bagdadi (v.463/1071), İbnu'n-Nedim'in zikrettiği bu esere sahipti (GAS IX 147)

\section{K. ed-Damair fi l-Kur'an}

Arapça'da zamirler sadece nahvin değil aynı zamanda Kur'an ilimleri arasında sayılan Garibu'l- Kur'an'ın da konusu olmuştur (İtkan, s. 263). Konuya girerken, lisani ve dini ilimlerde pek çok eser yazmış olan esSuyuti'nin el-İtkan fi ulumi'l-Kur'an adlı eserinde 'Kur'an-1 kerim bilgilerin kaynağıdır.' görüşünü hatırlatmak uygun düşecektir (el-İtkan, s. 17). O bu değerlendirmesini eserinin farklı yerlerinde, Fakih ondan hükümler çıkarır, dil âlimi ondan irabın kaidelerini kurar, sözdeki hataların bilinmesinde ona başvurur vb. ifadeler kullanarak ta destekler.

Es-Suyuti bu eserinin ortalarına doğru 462-465. sayfalarında 'müfessirin bilmesi gereken kaideler' arasında zamirleri ele alır ve 'İbn el-Enbari, Kur'an'da yer alan zamirleri açıklamak için iki cilt yazdı' diyerek bölüme (42. nev) başlar (s. 462). Bu rivayeti ilk olarak h.911/m.1505 yılında vefat eden es-Suyuti'nin nakletmiş olduğu görülüyor. Onun bu bilgiyi nereden naklettiği konusunda bir açıklama yapma gereği duymamış olması da dikkat çekicidir.

Es-Suyuti, İbnu'l-Enbari'nin Kur'an metninde yer alan zamirlere dair iki ciltlik bir eser yazdığını nereden bilmektedir diye düşünebiliriz. Bunun 
tespiti konusunda başvurduğumuz kaynaklar arasında bize yardımcı olanı Taşköprülü -zade'nin Miftahu's-se'ade'sidir. Büyük Osmanl1-Türk âlimi, h.948/m.1541 y1lında henüz Sahn-1 Seman'da hoca iken yazdığı söz konusu bu eserinde müfessirin sahip olması gereken bilgilerden bahsederken aradığımız bilgiyi de verir (II, 423). Daha sonra oğlu Kemaleddin Efendi de (v.1030/1621) babasının bu eserini tercümesinde aynı bilgiyi tekrarlayacaktır (Mevzu'atu'l-ulum II, 423). Öyle anlaşıllyor ki merhum Taşköprülü -zade, eseri Miftahu's-se'ade'yi yazarken, h. 830/1426 yıllarında yazılmış olan el-İtkan fi ulumi'l-Kur'an'dan da faydalanıordu. Zira elimizdeki el-İtkan nüshası h. 833/1429 tarihini taşıyor ki (mukaddime, s. 11) bu da onun literatüre hâkimiyeti konusunda müspet bir noktadır.

El-İtkan ve Miftahu's-se'ade'de Kur'an metninde görülen zamirlerle ilgili bu bilgi, daha sonra Katib Çelebi'nin (v.1067/1656) Keşfu'zzunun'unda da yer alacaktır (II, 1087). Ancak bu eserde Ebû Ali Ahmed b. Ca'fer ed-Dineveri'nin de Zama'ir el-Kur' an adlı bir kitabının olduğunu öğreniyoruz. ${ }^{1}$

es-Suyuti'nin Ebû Bekr İbn el-Enbari ile ilgili olarak verdiği diğer mühim bir bilgi de onun K:ur'an'da geçen garib kelimeler konusunda eser yazanlar arasında yer almasıdır. Bu rivayet aynen şöyledir: İçinde garib kelimelerin işlendiği eserlerin en meşhuru Kitabu'l-Uzeyzi'dir. Müellif elUzeyzi eseri üzerinde on beş yıl çalışmış, onu şeyhi Ebû Bekr İbn -Enbari ile birlikte yazmıştır (el-İtkan, s. 263). Eseri tahkik edip neşreden M. Ebu'l-Fadl İbrahim rivayetle ilgili herhangi bir not düşmediğinden söz konusu bu bilgi üzerinde durmamız gerekiyor. Her şeyden önce Kitabu'lUzeyzi diye tanıtılan eser, ez-Zubeydi'nin de dikkati çektiği gibi (en-

\footnotetext{
${ }^{1}$ Mısır'da yaşamış olan Ebû Ali ed-Dineveri, gittiği Basra'da Sibeveyhi'nin eseri el-Kitab fi nnahv'i önce el-Mazini'den okumuş, sonra da Bağdat'ta el-Muberrred'in derslerine katılmıştı (GAS IX, 205). Ebu Bekr Muhammed ez-Zubeydi (v.379/989), h.289/902 yılında vefat etmiş olan Ebû Ali ed-Dineveri'yi, Mısırlı nahivciler ve dil âlimleri arasında ikinci tabakaya yerleştirir ve şu bilgileri verir: Onun Kur'an'daki zamirlere dair muhtasar bir kitabı vardır. Bu kitabını el-Ferra'nın K. el-Me'ani'sinden istihrac etmiştir (Nuzhe 215)
} 
Nuzhe, 314) herhalde Ebû Bekr M. b. Uzeyr es-Sicistani'nin olmalıdır. ${ }^{1}$ es-Suyuti sözü geçen bu eserin yazarı olan alimi, h.899/m.1493 tarihinde hac ettikten sonra döndüğü Kahire'de son hazırlıklarını bitirip kaleme aldığı dilcilere ve nahivcilere dair eseri Bugyetu'l-vu'at fi tabakat ellugaviyyin ve n-nuhat'ta tanıtır sonra da eserin ve müellifinin adı ile ilgili olarak: Kitabını on beş yılda yazdığı, onu hocası İbnu'l-Enbari'ye okuduğu ve İbn el-Enbari'nin de (hataları) düzelttiği rivayet edildi, der (s. 72-73; ayrıca bk. En-Nuzhe, s. 314). Öyle anlaş1lıyor ki söz konusu bu eserin müellifi, önceleri bazı âlimlerce el-Uzeyz şeklinde verilmişse de doğrusu, yazma nüshalarında da görüldüğü üzere İbn Uzeyr esSicistani'dir (el-Bugye, s. 72-73).

\section{K. Muşkili'l-Kur'an}

Ebu'l-Berekat el-Enbari eseri Nuzhetu'l-udeba'da Sa'leb'in öğrencisi Ebû Omer ez-Zahid (Gulam Sa'leb)'ten bahsederken şu bilgiyi de verir: Ebû Omer ez-Zahid, Kadı Ebû Omer'in çocuğunu okuturken bir ara Ebû Bekr b. Dureyd, Ebû Bekr b. el-Enbari ve Ebû Bekr b. Miksem Kadı Ebû Omer'in huzurunda bir araya geldiler. Kadı, gündeme dil ile ilgili bazı meseleler getirdi. Onlar bunları tanımadıklarını ve şiiri beğenmediklerini söylediler. İbnu'l-Enbari, o zaman: Ben Muşkili'l-Kur'an'1 tasnifle uğraşıyorum (s. 378) demişti. İbnu'n-Nedim, İbnu'l-Enbari'nin bu kitabı tamamlayamadığını da kaydeder. (el-Fihrist,75; ayrıca bk. İnbah III,208).

\section{K. Nakd mesa'il İbn Şenebuz}

İbnu'n-Nedim, daha çok İbn Şenebuz diye tanınan kari Muhammed b. Ahmed b. Eyyub'ün (v.328/939) kıraatle ilgili bazı görüşlerinin tenkit edildiği bu kitabı da kaydeder (el-Fihrist s. 31$)^{2}$

İbnu'l-Enbari dile dair geniş ve güvenilir bilgisi ile tanınmıştı. $\mathrm{Bu}$ alandaki eserleri arasında şunlar hatırlatılmalıdır:

\footnotetext{
${ }^{1}$ Ez-Zubeydi bu görüşünü, hocası Ebû Mansur el-Cevaliki'nin bir rivayetine dayandırır (en-Nuzhe 314). Hocam Prof. Dr. Fuat Sezgin de söz konusu alimi Ebû Bekr b. Muhammed b. Uzeyr esSicistani olarak ele almaktadır (GAS I 43-44).

2 İbnu'n-Nedim hatalar yapan ve ilmi zayıf olan İbn Şenebuz'un bu görüşlerinden misaller de verir. el-Fihrist, 31-32.
} 
K. el-Addad (fi n-nahv)

El-Hatib el-Bagdadi, 'Bu konuda İbnu'l-Enbari’ninkinden daha büyük bir kitap görmedim' demektedir (Tarih Bagdad III, 184). Yazmaları günümüze kadar gelen (bk. Leiden Or. 552, 140 var., h. 652; Ch. Beatty 4533 (145 var.); Tal'at, luga 352 (224 var.) bu eser Leiden nüshasına dayanılarak basılmıştır: M. Th. Houtsma, Leiden 1881. GAS VIII 153)

\section{K. el-Emsal}

Eser hakkında sınırlı bilgi bulunmaktadır. (bkz. GAS VIII 152)

\section{Kaside fi muşkili'l-luga}

Kaynaklarda pek zikredilmeyen bu eserin yazma nüshaları arasında NO 4260/10 (vr. 66-74); Zahiriye 5433 (vr. 90a-98a). Diğer nüshaları için bkz. GAS VIII 152.

\section{K. ez-Zahir (fi me'ani kelimati'n-nas ya da fi me'ani'l-kelam fellezi yesta'miluhu n-nas)}

Abdurrahman Fehmi Bey'in, alimimizin en değerli ve meşhur eserlerinden biri olarak gördüğü ( Medresetu'l-Arab I, 63) bu kitabın bazı yazmalarını O. Rescher, daha XX. asrın başlarında şarkiyat dünyasına tanıtmıştı. Eserin baskıları da yapılmıştır : H.Ş. ed-Damin, Bagdad 1979 ; eş-Şirbini Şureyde, I-II, Kahire. Halkın kullandığı sözleri ele aldığı bu hacimli eserin günümüze ulaşan yazmaları arasında şunlar bilhassa kaydedilmelidir: Esad Ef. 3215 (3912, 1. Cilt, 209 var, h. 378; 3216 2. cilt, 352 var., h. 622; Fatih 3912 (304 var., h. 7. asır); Laleli 1787 (348 var., h. 1089 ); Veliyüddin 2597 (314 var., h. XII. asır); Feyzullah 1608 (200 var., h. 1089)

İbnu'l-Enbari kitabının mukaddemesinde "İnsanların namaz ve dualarında kullandığı sözlerin farkında olması, derece ve rütbe açısından en üstün bilgidir. Oysa onlar bu sözlerin anlamlarını bilmiyorlar. İşte ben bu kitabımda, namaz kılan Rabbine yaklaşırken kullandığı sözünün anlamını bilsin, dua eden Rabbinden ne istediğinin farkında olsun; tesbihatta bulunan Rabbini ne ile yücelttiğini idrak etsin diye bunları açıklıyorum" der. Sonra da bu açıklamalarına nahvin ve dilin inceliklerini ekleyeceğini hatırlatır. 
Gerçekten de eserde 'Hasbunallahu ve ni'me 1-vekil' (I 25-31); 'La havle vela kuvvete illa billah' (I, 31-41); 'Subhaneke'llahumme ve bihamdik' (I 89-92);' Et-tehiyyatu lillahi ves -salavatu ve t-tayyibat (I 101-103); Esselamu aleyke ve rahmetullah' (I 107-109) ve 'Amin' (I 109-111); 'Merhaben ehlen ve sehlen' (I 294-295); ' Helumme cerren' (I 445-447; 'Huve min etba eş-şeytan' (I 464-465); ' Lillahi derrruk' (I 468-469); ‘ Afallahu anke' (I 509-510); 'el-Hamdulillahi ve ş-şukru' (II 84-85); 'Reculun deyyus' (II 152-154) '; 'Filanun yahudiyyun' (II 221); 'Ekele fulanun el-uraka'(II 381-383); 'Fulanun vasiu'l-yed' (II 393-396) gibi deyişlerin söyleniş sebepleri, anlamları lügat (dil) nahiv açısından ele alınır ve şiirlerden örneklerle açıklanır.

İbnu'l-Enbari'nin şiir ile ilgisi de küçümsenecek gibi değildir. EzZubeydi (v. 379/989) bu konuda bir bilgi vermezken Bağdatlı İbnu'nNedim onun şiirle ilgili şu eserlerini kaydeder: K. el-Mufaddaliyat, K. esSeb' et-tıval, K. Şi'ri'r-Ra'i, Devavin min eş'ari'l-Arab (Şi'r Zuheyr ve'n-Nabiga'l-Ca'di ve'l-A'şa v.d). İbnu'n-Nedim'in verdiği bu liste daha sonraki müellifler tarafından, bazı ilaveler ve farklarla birlikte esas teşkil etmiş görünüyor.

Nitekim Ebu'l-Berekat el-Enbari, hadis, tefsir, tarih (ahbar) ve şiir konusundaki eserlerini hafızasından yazdırdığını (imla) söylediği Ebû Bekr b. el- Enbari'yi, şiir ve tefsirde devrinin en (büyük) hafızı olarak tanıtır (s.267) ve onun şiirle ilgili olarak Şerhu'l- Mufaddaliyat ve Şerhu'sSeb'i't-tival'ini kaydeder (s.264). ${ }^{1}$ Ebû Bekr b. el-Enbari'nin hafızası ile ilgili olarak Ebu'l-Berekat'ın rivayetlerine de yer veren Yakut el-Hamevi (XVIII, 306),? onun güzel (latif) şiirlerinden örnekler de kaydeder (s.311).

\footnotetext{
${ }^{1}$ Prof. Dr. Fuat Sezgin, Mu'llakat'a şerh yazanlar arasında Ebû Bekr b. el-Enbari'yi de hatırlatır ve şu yazma nüshaları kaydeder: Esat Ef. 2815, Turhan 278 (GAS II 50). El-Mufaddal b. Muhammed ed-Dabbi'nin, halife el-Mansur'un emri üzerine tertip ettiği el-Mufaddaliyyat adlı antolojisi de âlimimizin yakından ilgilendiği bir eser olmuştur. Yazma nüshaları arasında bk. Laleli 1858, AS 4099 (GAS II 53).
} 
Es-Suyuti, onun şiir ile ilgili eserlerini zikrederken bazı kısaltmalar da yapar. Mesela Şerh şi'r el-A'şa ile el-A'şa el-Meymun'u (ö.5/625) kastetmiş olmalıdır (GAS II 132). Şerh şi'ri'n-Nabiga ile en-Nabigatu'zZubyani (ö.604) kastedilmiş olmalıdır. Burada hatıra gelen en-Nabigatu'lCa'di'yi İbnu'n-Nedim, 'en-Nabiga ve'l-Cadi' diye hatırlatmıştı (elFihrist 75). Ebû Bekr b. el-Enbari, Emevi halifesi Yezid b. Mu'aviye devrinde hala hayatta olan bu şairin şiirleriyle de ilgilenmişti (GAS II 246).

Ne yazık ki bu eserlerin pek azı günümüze kadar gelebilmiştir. Benzer bir halin, âlimimizin nahve dair eserleri için de söz konusu olduğunu görmüştük. Böyle bir halin, onun eserlerini hafızasından imla etmesinden neş'et ettiğine dair bir rivayetle (İnbah III,204 ) karşılaşıyoruz. Söz konusu bu rivayette ifade edilen hal (hafizadan imla etme şekli), onun Garibu'lhadis, Şerhu'l-Kafi, K. el-Ha' at, K. el-Emsal ile aynı şekilde imla ettiği ve fakat Ta ha suresine kadar gelebildiği tefsire dair eseri ile İbn Kuteybe'yi ve Ebû Hatim es-Sicistani’yi tenkit ettiği eserleri (İnbah III 204) için de düşünülebilir..

Sünni görüşü benimsemiş güvenilir bir ravi olduğu zikredilen Ebû Bekr elEnbari evlenmemiş ve halife er-Radi'nin çocuklarının eğitimi ile de ilgilenmişti (en-Nuzhe, 267). K. Garibi'l-Kur'an sahibi olan arkadaş1 Ebu'l-Hasan el-Arudi'nin (el-Fihrist,35) anlattıkları, ${ }^{1}$ onun ezberlediklerini unutmamak için sıhhatine ve yediklerine dikkat ettiğini gösteriyor. Bir gün hastalandığında pek üzgün olan babası, geçmiş olsuna gelen ziyaretçilere -kitaplarla dolu bir sandığı işaret ederek - gördüğünüz bütün bunları ezberleyenin hastalığı için nasıl endişe edip üzülmeyeyim, demişti (en-Nuzhe, 271).

\footnotetext{
${ }^{1}$ Er-Radi'nin sarayında yemek için toplanmıştık. Aşçıbaşı onun ne yiyeceğini biliyordu. Biz çeşitli yemekler ve tatlılar yedik; o bir parça kızartılmış et (ciğer) yedi. Sonra serilmiş yaygı üzerinde uyuduk. İkindi olunca ' Hizmetçi, vazifeni hatırla!'dedi. O da bir bardak su getirdi, buzla kaplı suyu bıraktı. Ben bu şekilde davranışını yadırgadım ve 'Ey müminlerin emiri' diye bağırdım. Bunu duyan er-Razi, huzuruna getirilmemi emretti ve 'Ne yaptın? diye sordu. Ben de ' Ey müminlerin emiri, bu adam kendini öldürecek! Nefsine iyi davranmıyor' deyince halife güldü ve ' O bu halden memnun, âdeti bu dedi. Ben sonra ona 'Niye nefsine böyle davranıyorsun? diye sordum. Şöyle dedi: Hafizamdakileri koruyorum. (İnbah III )
} 
Kısa sayılabilecek ömrünü pek çok eser telif etmek, öğretim ve eğitimde bulunmakla geçiren alimimiz, adı geçen halife er-Radi'nin hilafeti (h.322329/m.934-940) devrinde h.326/m.937 yılının Zilhicce ayında, Kurban Bayramı gecesi Hakk'1n rahmetine kavuştu (İnbah III,206; en-Nuzhe, 271).

\section{Kaynaklar}

C. Brockelmann ; Geschicte du Arabischen Litteratur, (GAL I-II Supll I-IV), 1937-1942.

Ebü'l- Berekât Kemalüddin Abdurrahman b. Muhammed el- Enbârî; Nüzhetü'l- elibba' fî tabakâti'l-üdebâ', nşr: Ebü'l- Fazl İbrahim, Kahire1386/1967.

Ebû Tayyib el- Luğavî; Abdülvahid b. 'Ali el- Halebî; Meratibü'nnahviyyin, nşr: Muhammed Ebü’l- Fazl İbrahim, Kahire1957.

Fuat Sezgin; Geschichte des Arabischen Schrifttums, I-XIII, 1967-2000.

İbn Hallikân; Ebu'l- Abbas Şemsüddin Ahmed b. Muhammed Ebî Bekr b. Hallikân; Vefayâtü'l a'yân ve Enbâü'z- zaman mimma sebete bi'n-nakl evi's-sema' ev esbetehu'l- a'yân, nşr: Muhammed Muhyiddin Abdülhamit, I-IV,Kahire 1367/1948.

İbnü'l- Kıftî; İnbâhu'r-ruvat 'ala enbâhi'n- nuhât, nşr: Muhammed Ebü'lFazl İbrahim,I-II,Kahire 1369-1374/1950-1955

İbnü’n- Nedim; Muhammed b. İshâk en- Nedim, el_Fihrist, nşr: G. Flügel, Leipzig 1871-1872.

es-Suyutî; Abdurrahman b. Ebî Bekr Es- Suyutî, Buğyetü'l- vu'ât, I-VI, nşr: Muhammed Ebü'l- Fazl İbrahim, Kahire 1384/1964.

Yâkûtu'l- Hamavî; Ebû Abdillah Şihâbuddin Yâkût b. el- Hamavî, Mu'cemü'l- üdebâ', I-XX, nşr: Ahmed Ferîd er- Rifầ'̂,, Kahire 1355-1357.

ez- Zübeydî; Tabakâtü'n- nahviyyin ve'l- luğaviyyin, nşr; Muhammeb Ebü'l- Fazl İbrahim,Kahire 1952. 